International Journal of Food Science, Nutrition and Dietetics (IJFS)

ISSN 2326-3350

\title{
Oral Fluoride Including Drinking Water in Prevention of Tooth Decay
}

Vitoria $I^{182^{*}}$

${ }^{1}$ Nutrition and Metabolopathies Unit, Hospital La Fe. Valencia.

${ }^{2}$ Associate Professor of Pediatrics, University of Valencia, Spain.

\begin{abstract}
Herein we present a review of the role of oral fluoride in the prevention of tooth decay, together with updated recommendations on fluoride supplements. Fluoridation of public drinking water is still considered effective, but the recommended level of fluoride is now $0.7 \mathrm{mg} / \mathrm{L}$, compared with the previously recommended range of $0.7-1.2 \mathrm{mg} / \mathrm{L}$. Oral fluoride supplements are currently not restricted to the children at high risk for tooth decay, but recommended initiate at 6 months of age for all the children if their drinking water is deficient in fluoride. For infants more than six months, drinking water should contain 0.3 to $0.6 \mathrm{ppm}$ of fluoride, which avoids the need for additional supplements. We emphasise also the importance of considering the existing fluoride level in the drinking water and the age of the child when prescribing fluoride supplements.
\end{abstract}

Keywords: Oral Health; Toot Decay; Fluoride; Drinking Water; Dental Caries.

\section{*Corresponding Author:}

Isidro Vitoria,

Nutrition and Metabolopathies Unit, Hospital La Fe, Bulevar Sur s/n, 46021, Valencia (Spain).

Tel: 961244379

E-mail: vitoria_isi@gva.es

Recieved: April 13, 2015

Accepted: May 20, 2015

Published: May 21, 2015

Citation: Vitoria I (2015) Oral Fluoride Including Drinking Water in Prevention of Tooth Decay. Int J Food Sci Nutr Diet. 04(3), 197-201. doi: http://dx.doi.org/10.19070/2326-3350-1500036

Copyright: Vitoria $\mathbf{I}^{\circ}$ 2015. This is an open-access article distributed under the terms of the Creative Commons Attribution License, which permits unrestricted use, distribution and reproduction in any medium, provided the original author and source are credited.

\section{Introduction}

Fluoride is a nutrient that ensures healthy calcified tissues (bones and teeth) due to its high affinity for calcium. When used in the correct amount, fluoride increases bone density, reduces the risk of tooth decay, and promotes remineralization of tooth enamel [1].

The work of Dean et al., [2], showed a lower prevalence of tooth decay in geographical areas where the water contained more fluoride. Furthermore, they found that a fluoride concentration of 1 $\mathrm{ppm}$ in water was related to a maximum reduction of tooth decay and a minimum incidence of dental mottling. Dental mottling was later called dental fluorosis (DF) and was causally linked with fluo- ride intake or exposure. Seventy years later, the pathogenesis of tooth decay still is not fully understood, nor is the mechanism of its prevention by fluoride.

The prevalence of tooth decay in children has decreased in recent decades in most industrialized countries. This decrease was attributed to systemic fluoride (drinking water, beverages and food) and topical fluoride (toothpastes, gels and mouthwashes) and to improvements in nutritional health and dental hygiene. However, once again, we are witnessing an increase in the prevalence of tooth decay, especially in children from disadvantaged social sectors [3], possibly due to a suboptimal implementation of public health measures.

The above trend in the prevalence of tooth decay and new recommendations on the use of fluoride suggest the need for an updated report, focusing on the use of oral fluoride, where most changes have occurred. In our previous review on the role of fluoride in decay prevention [4], the ideal concentration of fluoride in water for an infant was $0.3 \mathrm{mg} / \mathrm{L}$ and oral fluoride supplements were recommended for children over six months, if they belonged to a high-risk group for tooth decay. The currently recommended fluoride level in water for infants is from 0.3 to $0.6 \mathrm{mg} / \mathrm{L}$.

\section{Action Mechanisms of Fluoride}

Fluoride has multiple mechanisms of action [5]. First, the hydroxyapatite crystals in the enamel become fluorapatite crystals, which are more resistant to decalcification. This chemical reaction is reversible and depends on the concentration of fluoride and acidity in the environment of the tooth enamel. Thus, the hydroxyapatite crystal begins to dissolve when the $\mathrm{pH}$ is less than 5.5 , whereas fluorapatite dissolves when the $\mathrm{pH}$ is less than 4.5 
(critical $\mathrm{pH}$ ). The process of dental demineralization and remineralization is a dynamic process for the whole of the tooth's lifetime. The reversibility of this mechanism justifies the recommendation for fluoride use over a lifetime without being restricted to the childhood. Second, the continuous use of low-dose topical fluoride induces dental remineralization.

Third, fluoride inhibits glycolysis in dental plaque bacteria (mainly Streptococcus mutans), thereby decreasing the formation of acids (mainly lactic acid), which initiate decomposition of hydroxyapatite into calcium and phosphate ions and water. Finally, fluoride acts also by decreasing the formation of bacterial polysaccharides which contribute to formation of the extracellular matrix of the dental plaque [6].

\section{Systemic Fluoride Action: what has changed?}

Sixty years ago, it was accepted that systemic fluoride supplementation exerted its maximum effect on tooth enamel during tooth development, while a certain amount of DF was an inevitable price to pay for the prevention of tooth decay. However, over the past 20 years, a radical change in the proposed action mechanism of fluoride in the prevention of tooth decay has gradually gained acceptance. First, evidence suggests that fluoride's fundamental preventive effect is due to its topical, rather than systemic action [7]. Second, since tooth decay appears to be reversible in its early stages, fluoride, through its remineralizing function, restores damage from initial demineralization. Therefore, it is now thought that topical fluoride, in small amounts over a lifetime, is the optimal method of administrating fluoride to prevent tooth decay [8].

\section{Dental Fluorosis}

$\mathrm{DF}$ is the consequence of hypo-mineralization of tooth enamel by excessive fluoride ingestion during enamel development, before tooth eruption. An increase in the prevalence of moderate $\mathrm{DF}$ is attributed to increased fluoride intake during tooth development. The severity of DF depends on the dose, duration, and time of the fluoride intake. Sources of fluoride that could lead to the development of DF at this stage in life include [9]:

\footnotetext{
- Toothpaste ingestion (especially up to 6 years of age).

- Improper use of oral fluoride supplements.

- Infant milk made with water containing more than $1 \mathrm{mg} / \mathrm{L}$ of fluoride.

- Food and beverages made with fluoridated water from public
}

water supplies.

Most studies on the period of maximum susceptibility to develop fluorosis focus on definitive mandibular incisors, as they have the greatest aesthetic impact. Based on current evidence, the period of greatest risk of DF from excessive fluoride intake is from birth to two to three years [10]. However, most consensus groups on systemic fluoride administration set the actual upper limit at the age of 6 years, since one of the most important factors, the ingestion of toothpaste, declines at this age because adequate coordination of the swallowing reflex has developed. Furthermore, at the age of six, the only remaining teeth susceptible to fluorosis are further back in the mouth and therefore have no serious aesthetic impact [11].

\section{Systemic Fluoride Requirement}

The dietary reference intakes (DRI) for fluoride refer to nutritional recommendations that can be used to plan and assess diets for healthy people. In the case of fluoride, two kinds of DRI have been set: adequate intakes (AI), for prevention of tooth decay and the tolerable upper intake level (UL) for prevention of DF.

The current $\mathrm{AI}$ is set at 0.01 to $0,5 \mathrm{mg}$ from birth to twelve months, $0.7 \mathrm{mg}$ from one to three years and $1 \mathrm{mg} /$ day from four to eight years. The UL is $0.7 \mathrm{mg} /$ day from birth to 6 months, 0.9 $\mathrm{mg} /$ day for seven to twelve months, $1.3 \mathrm{mg}$ /day for one to three years, and $2.2 \mathrm{mg} /$ day for four to eight years (Table 1) [12].

\section{Fluoride intake from water and food in small children}

Food sources contain variable amounts of dietary fluoride. Human milk contains 0.005 to $0.01 \mathrm{mg} / \mathrm{L}$ of fluoride, infant powder milk contains about $0.14 \mathrm{mg} / \mathrm{L}$, and cow's milk contains 0.03 to $0.06 \mathrm{mg} / \mathrm{L}$. Fruits, vegetables and meats, containing less than 1 $\mathrm{mg} / \mathrm{kg}$ of fluoride, are not a significant source [13]. However, tea can contain up to $150 \mathrm{mg} / \mathrm{kg}$ and some fish (tinned and smoked mainly) and shellfish can have $20 \mathrm{mg} / \mathrm{kg}$.

Fluoride intake from breast milk, powder milk, water, and various foods (which contribute between 0.2 and $0.77 \mathrm{mg}$ daily fluoride) have been calculated, based on average intakes for children of six months to three years of age (Table 2). In children under three years of age (when it is important not to exceed the UL to prevent DF), drinking water and water used to make infant milk contribute the most to daily fluoride intake.

Table 1. Dietary Reference Intake (DRI) for Fluorides.

\begin{tabular}{|c|c|c|}
\hline Age & AI* $\mathbf{( m g} /$ day $)$ & UL **(mg/day) \\
\hline $0-6 \mathrm{~m}$ & $0,01 \mathrm{mg}$ & $0,7 \mathrm{mg}$ \\
\hline $7-12 \mathrm{~m}$ & $0,5 \mathrm{mg}$ & $0,9 \mathrm{mg}$ \\
\hline $1-3 \mathrm{y}$ & $0,7 \mathrm{mg}$ & $1,3 \mathrm{mg}$ \\
\hline $4-8 \mathrm{y}$ & $1 \mathrm{mg}$ & $2,2 \mathrm{mg}$ \\
\hline $9-13 \mathrm{y}$ & $2 \mathrm{mg}$ & $10 \mathrm{mg}$ \\
\hline $14-18 \mathrm{y}$ & $3 \mathrm{mg}$ & $10 \mathrm{mg}$ \\
\hline $19->70$ & $4 \mathrm{mg}$ (males); $3 \mathrm{mg}$ (females) & $10 \mathrm{mg}$ \\
$\mathrm{y}$ & * AI: Adequate Intake \\
& ** UL: Upper Intake Level \\
\hline
\end{tabular}


Table 2. Estimated fluoride intake for children from 6 months to 3 years of agecompared to AI (adequate intake) and the UL (upper intake level).

\begin{tabular}{|c|c|c|c|c|}
\hline \multirow{2}{*}{ AGE } & \multicolumn{2}{|c|}{ 6-12 months } & \multicolumn{2}{|r|}{$1-3$ years } \\
\hline & \multicolumn{4}{|c|}{ Recommended fluoride intake } \\
\hline $\mathrm{AI}$ (mg/day) & \multicolumn{2}{|c|}{$0,5 \mathrm{mg}$} & \multicolumn{2}{|r|}{$0,7 \mathrm{mg}$} \\
\hline $\mathrm{UL}$ (mg/day) & \multicolumn{2}{|c|}{$0,9 \mathrm{mg}$} & \multicolumn{2}{|r|}{$1,3 \mathrm{mg}$} \\
\hline & \multicolumn{4}{|c|}{ Estimated fluoride intake } \\
\hline Water & $0,3-1,0 \mathrm{mg}$ & \multirow{3}{*}{$0,61-1,41 \mathrm{mg} /$ day } & $0,3-1,0 \mathrm{mg}$ & \multirow{3}{*}{$1,07-1,77 \mathrm{mg} /$ day } \\
\hline Breast/Powder Milk & $0,1-0,2 \mathrm{mg}$ & & & \\
\hline Diverse Foods & $0,21 \mathrm{mg}$ & & $0,77 \mathrm{mg}$ & \\
\hline
\end{tabular}

\section{Fluoridation of Public Drinking Water Supplies: changes in Recommendations}

In 2011, the Centers for Disease Control and Prevention (CDC), in accordance with the US Department of Health and Human Services, changed the recommended fluoride level in drinking water from the 1962 level of $0.7-1.2 \mathrm{ppm}$ to the current level of 0.7 ppm [14]. This change was based on several lines of evidence. First, there is growing scientific evidence that water fluoridation, at the recommended level, prevents tooth decay in all age groups both systemically and by the topical effect of continual exposure of tooth enamel to drinking water. Also, the increase in DF observed in recent years prompted a reduction in the upper limit. Finally, there is the evidence that the intake of water and fluids in children does not seem to increase with exposure to high ambient air temperature in developed countries, due to a greater use of air conditioning systems and children having a more sedentary life.

Although it is still accepted that water fluoridation is the best public health measure in areas of a high prevalence of tooth decay, in populations with a low prevalence of decay, the fluoridation of public drinking water is not the only option [15].

\section{What are the levels of Fluoride in the Public Drinking Water Supplies in Spain?}

In a recent study on the fluoride content of public drinking water supplies [16], including 110 Spanish cities where 21,387,496 people $(45.2 \%$ of the Spanish population) reside, the average concentration of fluoride was $0.25 \pm 0.23 \mathrm{mg} / \mathrm{L}(0.01$ to $1.34 \mathrm{mg} / \mathrm{L})$. Water from $95 \%$ of the cities studied contains less than the recommended level of $0.7 \mathrm{mg} / \mathrm{L}$, and there are 18 towns whose waters contain between 0.3 and $0.7 \mathrm{mg} / \mathrm{L}$. In only five towns, the concentration is greater than $0.7 \mathrm{mg} / \mathrm{L}$ : Vitoria and San Sebastián, by artificial fluoridation; San Cristóbal de La Laguna (Tenerife), by known natural fluoridation; and Ibiza and Leon, where the natural content is more than $1 \mathrm{mg} / \mathrm{L}$. It should be noted that fluoride concentrations in public drinking water may vary over time, depending on rainfall and changes in the concentration in aquifers or rivers.

\section{What is the Level of Fluoride in Natural Mineral waters in Spain?}

Traditionally, tap water has been considered as the most important component of total daily intake. However, in recent years there has been an increase in the consumption of natural mineral water.

According to a study from Maraver et al., [17], the average fluoride concentration of 97 Spanish natural mineral waters and 12 imported ones is 0.22 (range 0.00 to 4.16 ). The majority of waters (61 brands, 62\%) contain less than $0.3 \mathrm{mg} / \mathrm{L}$; however 19 brands contain more than $0.6 \mathrm{mg} / \mathrm{L}$, and eight of them contain more than $1 \mathrm{mg} / \mathrm{L}$. For imported waters, the average is 0.35 (range 0.10 to 1.21), including four brands containing more than $0.6 \mathrm{mg} / \mathrm{L}$.

The European legislation on labelling of natural mineral waters specifies that those with a fluoride concentration exceeding 1.5 $\mathrm{mg} / \mathrm{L}$ should include the indication that it "contains more than $1.5 \mathrm{mg} / \mathrm{L}$ of fluoride: not suitable for regular consumption by infants and children under 7 years" [18]. It also specifies that water containing more than $1 \mathrm{mg} / \mathrm{L}$ should include the term "fluoridated" [19]. As a result of these requirements, natural mineral water is a source of fluoride, with the dual advantages of providing a known fluoride concentration that is also stable over time.

\section{Oral fluoride Supplements}

Oral fluoride supplements are designed to provide fluoride to communities where water is not fluoridated. For this reason, the quantity of administered supplement depends on the concentration of fluoride in the drinking water.

Sodium fluoride, the standard compound used as a fluoride supplement, is absorbed at a rate of $90 \%$ to $97 \%$ if taken without food. Bioavailability decreases to $53.7 \%$ when taken with milk and other dairy products, so supplements should be taken on an empty stomach and a long time away from the consumption of dairy products, to prevent precipitation of calcium fluoride [20]. Sodium fluoride is distributed freely or bound to proteins and deposited on teeth and bone tissue. The distribution half-life is 1 hour, and it is mainly excreted in the kidneys. Drops can be used from six months to one or two years of age, then continuing with tablets. A stock solution to supplement drinking water can be prepared by dissolving $110 \mathrm{mg}$ of sodium fluoride in one litre of water, resulting in a final concentration of $0.25 \mathrm{mg}$ of fluoride ion per five $\mathrm{ml}$ of water. For topical application, fluoride in chewable tablets or tablets that dissolve by slow sucking, is ideal.

The Positions of the Various groups and committees on oral Fluoride supplements. What has changed?

In 1995, the American Academy of Pediatrics, in conjunction with the American Dental Association, revised their recommen- 
dations on the amounts of oral fluoride supplements for children from six months to 16 years of age, depending on the fluoride concentration in drinking water [21] (Table 3). In 2001, the same doses were endorsed by the CDC in the United States [22] and adopted by many other countries. These recommendations were more restrictive, with an upper limit of $0.6 \mathrm{mg} / \mathrm{L}$ compared to the previous limit of $0.7 \mathrm{mg} / \mathrm{L}$ (or ppm) of fluoride in water, and the fluoride concentration in drinking water for beginning supplements was revised.

To prevent the development of dental fluorosis, the American Academy of Pediatric Dentistry [23] and the American Academy of Pediatrics [24] started recommending use of fluoride supplements only for children with an increased risk of tooth decay in order to minimize the risk of dental fluorosis while preventing dental cariesThis trend was also adopted by the Committee on Nutrition of the Canadian Paediatric Society [25], the European Association of Paediatric Dentistry [26] and the PrevInfad group of the Spanish Association of Primary Paediatrics Health Care [27].

However, in 2014, the US Preventive Services Task Force revised its recommendations of 2004 on the prevention of tooth decay in children from birth to five years [28]. The Task Force now recommends that all children receive fluoride supplements accord- ing to fluoride levels in their drinking water. In fact, it states that all children are at risk for tooth decay, including children from low socio-economic backgrounds and children consuming high sugar foods, using medications such as antihistamines, incorrect use of baby bottles, and other factors listed in Table 4 .

The Oral Health Section of the American Academy of Pediatrics published a similar recommendation about the role of fluoride in preventing tooth decay, in the field of Primary Health Care [29], supporting the use of fluoride supplements according to fluoride levels in drinking water regardless of the assessed risk of tooth decay. To prevent fluorosis, the recommendation indicates that there should be no other sources of systemic fluoride.

The above recommendations emphasize the importance of assessing fluoride levels in public water supplies and other sources of drinking water, such as natural mineral water, before prescribing fluoride supplements. If the water from public supplies contains more than $0.6 \mathrm{ppm}$, no supplement should be given. The use of natural mineral water with known fluoride levels has the added advantage that its concentration remains stable over time. For infants and children from six months to three years of age, no fluoride supplements are needed if the water contains 0.3 to $0.6 \mathrm{ppm}$, but if it contains less than $0.3 \mathrm{ppm}$, oral fluoride supplements of $0.25 \mathrm{mg}$ per day are recommended.

Table 3. Recommended fluoride supplements depending on the concentration of fluoride in drinking water, according to the American Dental Association and the American Academy of Paediatrics (1995).

\begin{tabular}{|c|c|c|c|}
\hline AGE & $\begin{array}{c}\text { WATER FLUORIDE } \\
\mathbf{< 0 , 3} \mathbf{p p m}\end{array}$ & $\begin{array}{c}\text { WATER FLUORIDE } \\
\mathbf{0 , 3}-\mathbf{0 , 6} \mathbf{p p m}\end{array}$ & $\begin{array}{c}\text { WATER FLUORIDE } \\
\mathbf{7} \mathbf{0 , 6} \mathbf{~ p p m}\end{array}$ \\
\hline 6 MONTHS to 3 YEARS & $0,25 \mathrm{mg}$ & 0 & 0 \\
\hline 3 to 6 YEARS & $0,50 \mathrm{mg}$ & $0,25 \mathrm{mg}$ & 0 \\
\hline 6 to 16 YEARS & $1 \mathrm{mg}$ & $0,50 \mathrm{mg}$ & 0 \\
\hline
\end{tabular}

Table 4.Risk factors for childhood tooth decay.

\begin{tabular}{|l|l|}
\hline a) Harmful eating habits & $\begin{array}{l}\text { - Dummies or sweetened teats } \\
\text { - Sweetened baby bottles at bedtime } \\
\text { - Regular intake of sugars and sugar-sweetened drinks } \\
\text {-Sticky and sweet foods }\end{array}$ \\
\hline b) Factors related to dental hygiene & $\begin{array}{l}\text {-Orofacial deformities } \\
\text {-Orthodontic treatment } \\
\text { - Poor oral hygiene } \\
\text {-Serious mental disabilities (collaborative } \\
\text { difficulties) }\end{array}$ \\
\hline c) Factors related to xerostomia & $\begin{array}{l}\text { - Sjögren Syndrome } \\
\text { - Ectodermal dysplasia }\end{array}$ \\
\hline d) Illnesses with high risks in dental operations & $\begin{array}{l}\text { - Heart disease } \\
\text { - Immunosuppression (including HIV) } \\
\text { - Haemophilia and other blood clotting disorders }\end{array}$ \\
\hline e) Socioeconomic Factors & $\begin{array}{l}\text { - Low socio-economic level (especially if associated with } \\
\text { bad eating and hygiene habits) }\end{array}$ \\
\hline f) Others & $\begin{array}{l}\text {-Family background of tooth decay } \\
\text {-Active tooth decay, regardless of age }\end{array}$ \\
\hline
\end{tabular}

Modified from Canadian, American and European focus groups 


\section{Conclusion}

In conclusion, we have reviewed the practical use of oral fluoride in the prevention of tooth decay and highlighted the following major developments:

- $\quad$ Fluoride should be supplemented to all the children above 6 months of age if their drinking water is deficient in fluoride.

- If drinking water contains $03-0.6 \mathrm{mg} / \mathrm{L}$ of fluoride, fluoride supplementation is not necessary for children from 6 months to 3 years.

- Oral fluoride supplements, at doses based on the age of the children and the existing fluoride level in the drinking water should be extended to all the children, without restricting to the children at high risk for tooth decay.

\section{References}

[1]. Warren JJ, Levy SM (2003) Current and future role of fluoride in nutrition. Dent Clin North Am 35:390-391.

[2]. Dean HT, Arnold FA Jr, Evolve E (1942) Domestic water and dental caries V. Additional studies of the relation of fluoride domestic waters to dental caries experience in 4425 white children aged 12-14 years of 13 cities in 4 states. Publ Health Rep 57:1155-1179

[3]. Schwendicke F, Dörfer C. E, Schlattmann P, Page L. F, Thomson, et al. (2015) Socioeconomic Inequality and Caries A Systematic Review and Meta-Analysis. Journal of dental research 94(1):10-18.

[4]. Vitoria I (2010) Fluoride and the prevention of dental caries in chilhood. Update (I).Acta Pediatr Esp 68:129-134

[5]. Robinson C (2009) Fluoride and the caries lesion: interactions and mechanism of action.Eur Arch Paediatr Dent 10:136-140

[6]. Clarkson JJ, McLoughlin (2000) Role of fluoride in oral health promotion. Int Dent J 50:119-128

[7]. Hellwig E, Lennon AM (2004) Systemic versus topical fluoride.Caries Res 38:258-262

[8]. Rošin-Grget K, Peroš K, Sutej I, Bašić K (2013) The cariostatic mechanisms of fluoride. Acta Med Acad 42:179-88.

[9]. Buzalaf M. A. R, Levy S. M (2011) Fluoride intake of children: considerations for dental caries and dental fluorosis. Monographs in oral science (22) 1-19.

[10]. Levy SM, Broffitt B, Marshall TA, Eichenberger-Gilmore JM, Warren JJ (2010) Associations between fluorosis of permanent incisors and fluoride intake from infant formula, other dietary sources and dentifrice during early childhood. J Am Dent Assoc 141:1190-1201.

[11]. Abanto JA, Rezende KMPC, Marocho SMS, Alves FBT, Celiberti P et al.(2009) Dental fluorosis: Exposure, prevention and management. Med Oral Patol Oral Cir Bucal 14:103-7.
[12]. National Academy of Sciences. Institute of Medicine. Food and Nutrition Board (1997) Fluoride. In: Dietary Reference Intakes for Calcium, Phosphorus, Magnesium, Vitamin D, and Fluoride.Washington: National Academies Press. 288-313.

[13]. Taves DR (1983) Dietary intake of fluoride ashed (total fluoride) v. unashed (inorganic fluoride) analysis of individual foods. Br J Nutr 49:295-301.

[14]. The Daily Journal of the United States Government. Proposed HHS recommendation for fluoride concentration in drinking water for prevention of dental caries. Available from https://federalregister.gov/a/2011-637. [cited: 30th Nov 2014].

[15]. WHO. Guidelines for drinking-water quality (2011) 4th ed. Geneva: World Health Organization ed.

[16]. Vitoria I, Maraver F, Almerich-Silla JM (2014) Fluoride content in tap water in Spain and prevention of dental caries. Gac Sanit 28:255-256.

[17]. Maraver F, Vitoria I, Almerich-Silla JM, Armijo F (2015) Fluoride content of bottled natural mineral waters in Spain and prevention of dental caries . Aten Primaria 47:15-24.

[18]. http://faolex.fao.org/cgibin/faolex.exe?rec_id=029582\&database=faolex \&s earch_type=link\&table=result\&lang=eng\&format_name=@ERALL Commission Directive 2003/40/EC of 16 May 2003 establishing the list, concentration limits and labelling requirements for the constituents of natural mineral waters and the conditions for using ozone-enriched air for the treatment of natural mineral waters and spring waters.

[19]. http://faolex.fao.org/cgibin/faolex.exe?rec_id=072313\&database=faolex\&s earch_type=link\&table=result\&lang=eng\&format_name=@ERALL Directive 2009/54/EC of the European Parliament and of the Council of 18 June 2009 on the exploitation and marketing of natural mineral waters

[20]. Sampaio FC, Levy SM (2011) Systemic fluoride. Monogr Oral Sci.22:13345.

[21]. Klish W. J, Susan C, Baker M. D, Georgieff M. K, Lake A. M, et al. (1995) Fluoride supplementation for children: interim policy recommendations 95:777.

[22]. Kohn W. G, Maas W. R, Malvitz D. M, Presson S. M, Shaddix, K. K (2001) Recommendations for using fluoride to prevent and control dental caries in the United States. Morbid. Mortal. Wkly Rep 50: 1-42.

[23]. American Academy on Pediatric Dentistry (2008) Guideline on fluoride therapy. Pediatr Dent 30:121-124

[24]. American Academy of Pediatrics (2008) Section on Pediatric Dentistry and Oral Health. Preventive oral health intervention for pediatricians. Pediatrics 122:1387-1394.

[25]. Nutrition Committee, Canadian Paediatric Society (2002)The use of fluoride in infants and children. Paediatr Child Health 7:569-572.

[26]. European Academy of Paediatric Dentistry (2009) Guidelines on the use of fluoride in children: an EAPD policy document. Eur Arch Paediatr Dent 10:129-135

[27]. Vitoria I, Grupo Previnfad/PAPPS Infancia y Adolescencia (2011) Dental health promotion. Rev Pediatr Aten Prim 13:435-458

[28]. Moyer VA; US Preventive Services Task Force (2014) Prevention of dental caries in children from birth through age 5 years: US Preventive Services Task Force recommendation statement. Pediatrics 133:1102-1111.

[29]. Clark MB, Slayton RL (2014) Section on Oral Health.Fluoride use in caries prevention in the primary care setting. Pediatri134:626-63 